\title{
MENINGKATKAN PEMAHAMAN KONSEP ALJABAR DAN KETERAMPILAN PROSES MATEMATIKA SISWA SMPN 1 KUSAN HILIR KELAS VII E DENGAN MODEL PEMBELAJARAN INKUIRI TERBIMBING TAHUN PELAJARAN 2014/2015
}

\author{
Junaidi $^{1}$ \\ 1. SMP Negeri 1 Kusan Hilir, Pagatan, Tanah Bumbu \\ junaidialdi83@gmail.com (081349577730)
}

\begin{abstract}
ABSTRAK
SMPN 1 Kusan Hilir adalah sebuah sekolah yang berpotensi untuk dikembangkan sebuah model maupun metode pembelajaran secara kontekstual. Rendahnya hasil belajar dikarenakan pembelajaran masih terpaku oleh papan tulis di sekolah. Salah satu variasi model pembelajaran agar siswa lebih aktif sehingga keberhasilan belajar di ajarkan dan keterampilan proses dapat meningkat diantaranya adalah pembelajaran menggunakan model inkuiri terbimbing. Penelitian ini bertujuan untuk meningkatkan pemahaman dan keterampilan proses matematika siswa, mengetahui aktivitas siswa, dan respon siswa terhadap pembelajaran inkuiri terbimbing pada konsep aljabar Penelitian ini merupakan penelitian tindakan kelas yang direncanakan 2 siklus, siklus I dan siklus II yang terdiri dari 2 kali pertemuan. Penelitian ini mengunakan analisis kualitatif berupa angket dan analisis kuantitatif berupa nilai tes Subjek. Penelitian ini adalah siswa kelas VII E SMPN 1 Kusan Hilir sebanyak 24 orang. Berdasarkan hasil penelitian menunjukkan bahwa pembelajaran dengan menggunakan model inkuiri terbimbing dapat meningkatkan pemahaman dan keterampilan proses matematika untuk ketuntasan klasikal siklus I pada pretes yaitu $12 \%$ menjadi $33,33 \%$ dan postes siklus I sebesar $29,16 \%$ menjadi $54,16 \%$. Untuk siklus II hasil belajar siswa pada ketuntasan klasikal pretes yaitu $45,83 \%$ menjadi $62,5 \%$, sedangkan pada postes yaitu $79,16 \%$ menjadi $91,67 \%$. Keterampilan proses matematika siswa dari siklus 1 pertemuan 1 diperoleh 14,83 menjadi 15.54 pada pertemuan 2 dengan kategori baik. Pada siklus II meningkat menjadi 15.79 pada pertemuan 3 dan 17.71 pada pertemuan 4 dengan kategori baik sekali. Aktivitas siswa dari siklus I diperoleh rata-rata 3,17 dengan kategori baik, pada siklus II meningkat menjadi 3,69 dengan kategori baik. Penggunaan model pembelajaran inkuiri terbimbing menunjukan respon baik oleh siswa karena banyaknya siswa yang merasa menyenangkan dan termotivasi mengikuti pembelajaran.
\end{abstract}

Kata Kunci: Inkuiri Terbimbing, Pemahaman konsep, keterampilan proses matematika, aljabar

\section{A. Latar Belakang}

\section{PENDAHULUAN}

Salah satu masalah yang dihadapi dunia pendidikan kita adalah masalah lemahnya proses pembelajaran. Dalam proses pembelajara, anak kurang didorong untuk mengembangkan kemampuannya berpikir (Sanjaya,2007:1). Menurut Undang.undang RI nomor 20 tahun 2003 tentang Sistem Pendidikan Nasional 
menyatakan bahwa pendidikan adalah usaha sadar dan terencana untuk mewujudkan suasana belajar dan proses pembelajaran agar peserta didik secara aktif mengembangkan potensi dirinya untuk memiliki kekuatan spiritual keagamaan, pengendalian diri, kepribadian, kecerdasan, akhlak mulia, serta keterampilan yang diperlukan dirinya, masyarakat, bangsa, dan negara (Sanjana, 2007: 2).

Harapan yang tidak pernah sirna dan selalu guru tuntut adalah bagaimana bahan pelajaran yang disampaikan guru dapat dikuasai oleh anak didik secara tuntas. Ini merupakan masalah yang cukup sulit yang dirasakan oleh guru. Kesulitan itu dikarenakan anak didik bukan hanya sebagai individu dengan segala keunikannya tetapi mereka juga sebagai makhluk sosial dengan latar belakang yang berlainan (Zain, 2006: 1).

Kondisi serupa juga terjadi di SMP Negeri 1 Kusan Hilir, sebuah sekolah yang berpotensi untuk dikembangkannya sebuah model maupun metode pembelajaran secara kontekstual. Minimnya pemahaman siswa dalam belajar dikarenakan pembelajaran masih terpaku oleh papan tulis saja, sehingga tidak memunculkan pengalaman baru yang dialami oleh peserta didik pada setiap kegiatan pembelajaran di sekolah. Pendekatan keterampilan proses dengan pembelajaran teoritis, cara pendekatan konvensional yang tidak efektif merupakan komponen penyebab timbulnya kejenuhan siswa belajar di dalam kelas.

Berdasarkan hasil wawancara dengan guru matematika SMPN 1 Kusan Hilir bahwa konsep aljabar termasuk konsep yang sulit dipahami oleh siswa. Hal ini terlihat dari hasil ulangan siswa kelas VII tahun pelaajaran 2013/2014 dengan nilai ketutasan klasikal 65\% yang tidak mencapai KKM 75, artinya secara klasikal siswa belum tuntas dalam belajar konsep ini, karena masih di bawah batas standar ketuntasan klasikal yang diharapkan sebesar 85\%. Hal itu dikarenakan pembelajaran masih menggunakan metode diskusi dan ceramah saja, sehingga siswa masih kurang mendapat pengalaman dan membuat hasil belajar dan keterampilan proses matematika siswa yaitu keterampilan yang dipelajari siswa pada saat mereka melakukan pembelajaran kurang memuaskan. Diharapkan pada saat mereka terlibat aktif dalam menggunakan berbagai macam keterampilan proses matematika bukan hanya satu metode ilmiah tunggal. Keterampilan proses matematika dikembangkan bersama-sama dengan fakta-fakta, konsep-konsep, dan prinsi-prinsip matematika. Keterampilan proses matematika yang mengarah pada pengembangan kemampuan mental, fisik, dan sosial yang mendasar sebagai penggerak kemampuan yang lebih tinggi dalam diri individu siswa. Agar anak didik berhasil dalam pembelajaran gurulah yang sangat berperan penting. Zain (2006: 112) mengemukakan bahwa gurulah dengan keilmuan yang dimiliki dapat menjadikan anak didik menjadi orang yang cerdas dan berhasil dalam pembelajaran.

Salah satu variasi model pembelajaran agar siswa lebih aktif sehingga keberhasilan belajar yang diajarkan dapat meningkat diantaranya adalah pembelajaran menggunakan model inkuiri terbimbing. Model inkuiri terbimbing 
membuat anak didik aktif didalamnya sehingga tidak menimbulkan bosan karena anak didik yang melakukan kegiatan sehingga ingin tahu tentang materi yang diberikan.

\begin{tabular}{|l|}
\hline 1. Menyajikan pertanyaan atau masalah \\
\hline 2. Membuat Hipotesis \\
\hline 3. Merancang percobaan \\
\hline $\begin{array}{l}\text { 4. Melakukan percobaan untuk memperoleh } \\
\text { informasi }\end{array}$ \\
\hline 5. Mengumpulkan dan menganalisis data \\
\hline 6. Membuat kesimpulan \\
\hline
\end{tabular}

Ahmadi (2011: 25) mengatakan inkuiri adalah kegiatan pembelajaran yang melibatkan secara maksimal seluruh kemampuan dan keterampiln proses sains siswa dalam memahami konsep untuk mencari dan menyelidiki sesuatu secara sistematis, kritis, logis, analitis, sehingga mereka dapat merumuskan sendiri penemuannya dengan penuh percaya diri. Pembelajaran inkuiri merupakan suatu srategi yang membutuhkan siswa menemukan sesuatu dan mengetahui bagimana cara memecahkan masalah dalam suatu penelitian ilmiah. Tujuan utamanya adalah mengembangkan sikap dan keterampilan siswa yang memungkinkan mereka menjadi pemecah masalah yang mandiri.

Berawal dari upaya untuk meningkatkan keterampilan proses matematika siswa, maka peneliti melakukan penelitian tentang Meningkatkan Pemahaman Konsep aljabar Siswa SMP Negeri 1 Kusan Hilir dengan Model Pembelajaran Inkuiri Terbimbing.

\section{B. Model Pembelajaran Inkuiri Terbimbing}

Menurut Sanjaya (2011: 196), model inkuiri adalah rangkaian kegiatan pembelajaran yang menekankan pada proses berpikir secara kritis dan analitis untuk mencari dan menemukan sendiri jawaban dari suatu masalah yang dipertanyakan. Proses berpikir itu sendiri biasanya dilakukan melalui tanya jawab antara guru dan siswa.

Langkah-langkah model pembelajaran inkuiri terbimbing yang akan digunakan pada penelitian ini diadaptasi dari langkah-langkah model pembelajaran inkuiri menurut Eggen dan Kauchak (1996). Adapun tahapan pembelajaran inkuiri terbimbing sebagai berikut:

\section{A. Subyek Penelitian}

\section{METODE}

Subjek penelitian ini adalah siswa kelas VII E SMPN 1 Kusan Hilir yang berjumlah 24 siswa yang terdiri 13 orang siswa laki-laki dan 11orang siswa perempuan.

\section{B. Teknik Pengumpulan Data}

Data yang diambil dari penelitian ini adalah data kuantitatif yaitu data hasil belajar yang diambil dari hasil tes serta hasil selama proses pembelajaran. 
Tes dilakukan dengan memberikan serangkaian soal kepada siswa yang berbentuk objektif. Sedangkan data kualitatif berupa data hasil observasi, observasi siswa, aktivitas siswa dalam kegiatan belajar mengajar dan angket respon siswa terhadap pembelajaran menggunakan model inkuiri terbimbing pada konsep aljabar.

\section{Rencana Tindakan}

Penelitian ini dirancang 2 siklus dengan 4 kali pertemuan. Jenis penelitian yang digunakan adalah Penelitian Tindakan Kelas (PTK). Oleh karena itu langkah-langkah penelitian ini dilakukan dengan mengikuti prosedur atau ketentuan penelitian tindakan kelas sebagai berikut :
a. Perencanaan
b. Pelaksanaan dan Tindakan
c. Observasi dan Evaluasi
d. Analisis dan Refleksi

HASIL PENELITIAN DAN PEMBAHASAN

A. Keterampilan Proses matematika Siklus I dan II

\begin{tabular}{|l|c|c|c|c|}
\hline \multirow{2}{*}{\multicolumn{1}{|c|}{ Indikator }} & \multicolumn{2}{c|}{ Siklus I } & \multicolumn{2}{c|}{ Siklus II } \\
\cline { 2 - 5 } & 1 & 2 & 3 & 4 \\
\hline Merumuskan masalah & 2.54 & 2.96 & 3 & 3.42 \\
\hline Merumuskan hipotesis & 2.83 & 3 & 3.04 & 3.29 \\
\hline Mengumpulkan data, melakukan & 3.17 & 3.17 & 3.25 & 3.67 \\
\hline Menganalisis data & 3.08 & 3.13 & 3.13 & 3.54 \\
\hline Membuat kesimpulan & 3.21 & 3.33 & 3.38 & 3.79 \\
\hline
\end{tabular}

Berdasarkan Tabel diatas dapat dibuat grafik sebagai berikut:

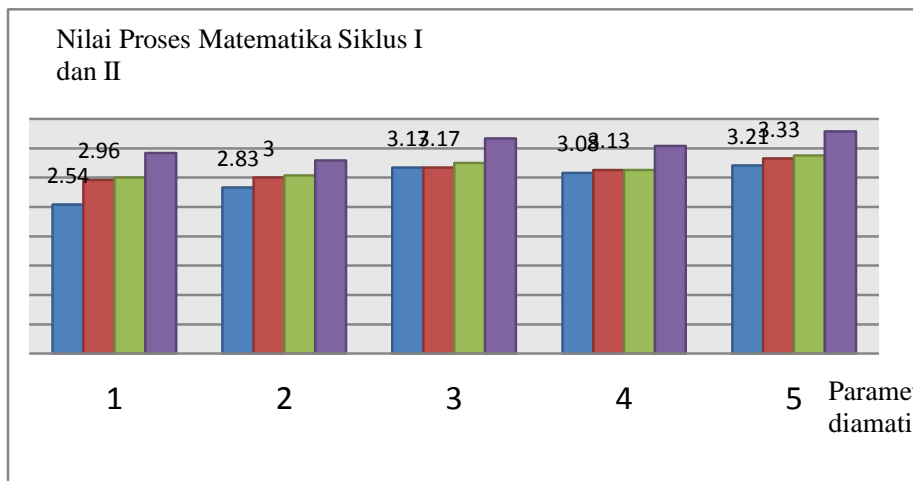

Gambar 2.hasil keterampilan proses matamatika siklus I dan II 
Meningkatkan Pemahaman Konsep Aljabar dan Keterampilan Proses Matematika

Siswa SMPN 1 Kusan Hilir Kelas VII E dengan Model Pembelajaran Inkuiri Terbimbing Tahun Pelajaran 2014/2015

\section{B. Pemahaman Siswa}

\begin{tabular}{|c|c|c|c|}
\hline \multicolumn{2}{|c|}{ Ketuntasan Klasikal } & Siklus I & Siklus II \\
\hline \multirow{2}{*}{ Pertemuan I dan III } & Pretest & $12 \%$ & $69,58 \%$ \\
\cline { 2 - 4 } & Postest & $29,16 \%$ & $79,16 \%$ \\
\hline \multirow{2}{*}{ Pertemuan II dan IV } & Pretest & $33,33 \%$ & $62,5 \%$ \\
\cline { 2 - 4 } & Postest & $54,16 \%$ & $92 \%$ \\
\hline
\end{tabular}

Gambar 1. Hasil Pretest dan Postest Siklus I dan Siklus II

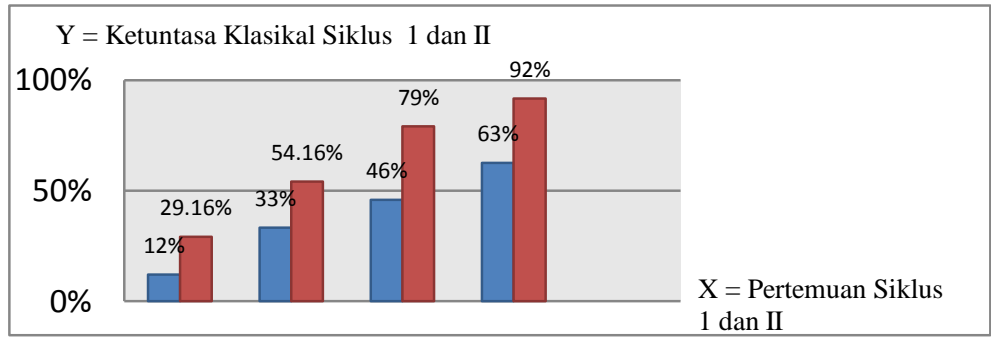

\section{Aktifitas siswa}

\section{Keaktifan Siswa}

\begin{tabular}{|l|c|c|c|c|}
\hline \multirow{2}{*}{ Indikator } & \multicolumn{2}{c|}{ Siklus I } & \multicolumn{2}{c|}{ Siklus II } \\
\cline { 2 - 5 } & 1 & 2 & 3 & 4 \\
\hline Menyimak Penjelasan Guru & 3,21 & 3,33 & 3,63 & 3,83 \\
\hline Merumuskan masalah dan hipotesis & 3,08 & 3,17 & 3,58 & 3,75 \\
\hline Melakukan pengamatan/penyelidikan & 3,04 & 3,17 & 3,5 & 3.79 \\
\hline Diskusi kelompok & 3,08 & 3,33 & 3,54 & 3,88 \\
\hline Mempresentasikan hasil pengamatan & 3,04 & 3.17 & 3,54 & 3,79 \\
\hline
\end{tabular}

Berdasarkan Tabel diatas dapat dibuat grafik sebagai berikut:

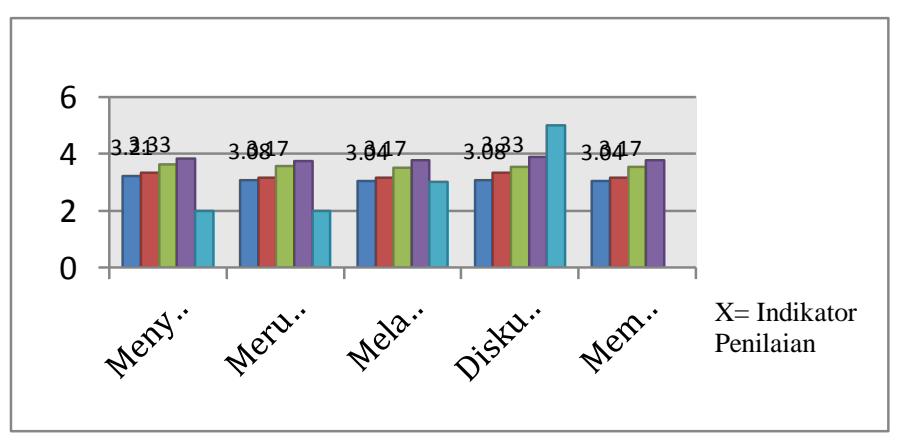


Gambar 3. Keaktifan Siswa Siklus I dan Siklus II

\section{Ketidak Terlibatan Siswa dalam Kegiatan Pembelajaran}

\begin{tabular}{|l|c|c|c|c|}
\hline \multirow{2}{*}{$\begin{array}{c}\text { Ketidak keterlibatan siswa dalam } \\
\text { kegiatan pembelajaran) }\end{array}$} & \multicolumn{2}{c|}{ Siklus I } & \multicolumn{2}{c|}{ Siklus II } \\
\cline { 2 - 5 } & 1 & 2 & 3 & 4 \\
\hline Mengantuk & 0 & 0 & 0 & 0 \\
\hline Mengerjakan tugas lain & $12,5 \%$ & $12,5 \%$ & $4,2 \%$ & 0 \\
\hline Berbisik & $4,2 \%$ & $4,2 \%$ & 0 & 0 \\
\hline Keluar masuk & 0 & 0 & $8,3 \%$ & $4,2 \%$ \\
\hline Menggangu siswa lain & 0 & 0 & 0 & 0 \\
\hline Melamun & $4,2 \%$ & $8,3 \%$ & $4,2 \%$ & $4,2 \%$ \\
\hline Usil & $\%$ & 0 & 0 & 0 \\
\hline Membuat coret-coretan dikertas & $4,2 \%$ & $4,2 \%$ & $4,2 \%$ & $4,2 \%$ \\
\hline Nyeletuk & $4,2 \%$ & 0 & $4,2 \%$ & $4,2 \%$ \\
\hline Pindah-pindah tempat duduk & 0 & 0 & 0 & 0 \\
\hline
\end{tabular}

Tabel 3. Ketidak keterlibatan siswa dalam kegiatan pembelajaran Siklus I dan Siklus II

\section{Respon Siswa Terhadap Proses Pembelajaran}

Untuk jawaban no satu 19 siswa menjawab mudah faham dan mengerti dengan pelajaran,dan lebih termotivasi dalam mengikuti pelajaran dan lima orang menjawab mudah mengetahui segala yang belum diketahui melalui diskusi dengan teman.

Untuk jawaban no dua, 23 siswa menjawab menyenangkan dan satu orang siswa menjawab tegang dan sedikit malu.Untuk jawaban no tiga 12 siswa menjawab tidak ada hambatan 12 siswa mejawab masih kesulitan saat menjawab soal pretes dan masih agak malu saat disuruh prosentasi. Untuk jawaban no empat 23 siswa menjawab meningkat, dan 1 siswa menjawab baik. Untuk jawaban no lima 23 siswa menjawab lebih ditingkatkan dan bukan hanya pada pelajaran matematika saja 1 orang menjawab tidak ada.

\section{Pembahasan}

\section{Penilaian Proses matematika Siklus I dan Siklus II}

Penilaian keterampilan proses matematika ini dimaksudkan untuk mengetahui sejauh mana siswa dapat berpartisipasi dalam mengikuti pembelajaran, keaktifan menggunakan pikiran dan sikap ilmiah. Pada setiap pertemuan baik siklus I atau pun siklus II penilaian keterampilan proses matematika siswa selalu mengalami peningkatan, yang mana pada siklus I masih berkategori baik meningkat menjadi sangat baik di siklus II. 
Meskipun demikian, dalam proses inkuiri terbimbing sebagian siswa kurang bisa merumuskan hipotesis dari permasalahan yang diidentifikasi. Mereka masih awam terhadap arti dan maksud dari hipotesis tersebut. Pada asfek lain seperti mengumpulkan data mereka terlihat cukup aktif dan antusias karena dalam proses pembelajaran mereka tidak hanya mendengarkan penjelasan dari guru tetapi mereka berusaha menemukan sendiri apa yang mereka cari dengan panduan LKS yang telah diberikan oleh guru, meskipun mengalami sedikit kesulitan. Juga pada saat menyimpulkan pelajaran tampak siswa belum secara lengkap mengungkapkan apa yang diperolehnya dari proses pembelajaran, mereka kesulitan menyimpukan dengan kata-kata sendiri sehingga guru masih harus membimbing dalam penarikan kesimpulan.

Dari hasil penilaian proses menunjukan bahwa proses belajar mengalami peningkatan dari siklus 1 kesiklus 2. Peningkatan proses belajar siswa ini disebabkan karena siswa merasa senang belajar dengan mengunakan model pembelajaran inkuiri terbimbing.

Sikap yang demikian sesuai dengan hasil respon siswa dimana semua siswa merasa senang dengan pembelajaran inkuiri terbimbing. Sehingga secara keseluruhan siswa sudah mengotimalkan dan meningkatkan kinerja prosesnya dalam setiap pertemuan. Hal ini sejalan dengan teori belajar oleh Trusman Hakim dalam Fathurrohman (2007: 5) mengartikan belajar adalah suau proses perubahan dalam kepribadian manusia, dan perubahan tersebut ditampakan dalam bentuk peningkatan kualitas dan kuantitas tingkah laku.

\section{Pemahaman Siswa}

Berdasarkan data yang diperoleh, ketuntasan belajar siswa mengalami peningkatan pada tiap pertemuan. Hal ini sejalan dengan tujuan penelitian telah tercapai dengan terpenuhinya indikator keberhasilan untuk ketuntasan belajar karena ketuntasan belajar dianggap berhasil jika $\geq 85 \%$ dari seluruh siswa mencapai nilai individu $\geq 75$

Ketuntasan belajar dilihat dari nilai soal mengerjakan pretes dan postes yang diberikan oleh guru. Pretes bertujuan untuk mengetahui kemampuan awal yang memiliki peserta didik mengenai bahan ajar dalam proses pembelajaran, sedangkan tujuan dari postes untuk mengetahui tingkat penguasaan peserta didik terhadap kompetensi dasar yang telah ditentukan, bahwa tinggi- rendahnya hasil belajar yang dicapainya bergantung pada usaha dan motivasi belajar diri sendirinya (Sudjana.N:2009).

Pada siklus I terlihat bahwa pada nilai pretes belum mencapai ketuntasan klasikal yang ditetapkan yaitu $\geq 85 \%$ dari siswa dalam kelas mencapai ketuntasan individu. Pada siklus I, nilai pretes pertemuan 1 adalah $12 \%$ dan pertemuan 2 adalah $33.33 \%$. Begitu juga ketuntasan klasikal yang diperoleh dari postes pada siklus I pertemuan 1 dan 2 juga belum mencapai ketuntasan klasikal yang diterapkan karana ketuntasan klasikalnya hanya 29,16\% dan 54,16\%. Belum tuntasnya pembelajaran disebabkan penggunaan pembelajaran model inkuiri terbimbing yang masih baru bagi siswa, sehingga pelaksanaan belum optimal dan siswa belum termotivasi belajar. Hal ini sejalan dengan pendapat teori Gestalt dalam Slameto (2010) belajar yang penting adalah adanya penyesuaian pertama 
yaitu memperoleh respon yang tepat. Penyesuaian ini timbul dari dalam diri seseorang dan juga berhubugan dengan kedewasaan. Karena kedewasaan berarti kesiapan untuk melaksanakan kecakapan. Maka hasil belajarnya akan baik dan maksimal. Berdasarkan observasi pada siklus I, guru dan siswa telah melakukan kegiatan pembelajaran yang sesuai dengan model pembelajaran model inkuiri terbimbing, tetapi masih terdapat kekurangan-kekurangan dimana kekurangankekurangan itu ada sebagian dari guru dan juga terdapat pada siswa. Diantaranya ada sebagian siswa yang tidak memperhatikan penjelasan guru saat guru menyampaikan materi,. Melihat kekurangan-kekurangan yang masih ada serta prestasi belajar matematika siswa terhadap Konsep aljabar tindakan siklus I belum mencapai indikator keberhasilan yang telah ditetapkan, maka penelitian dilanjutkan ke siklus II Menurut Suryosubroto.B (2009) Kelemahan-kelemahan yang masih terdapat dalam bagian - bagian tertentu dari program yang kita berikan, sehingga memberikan pedoman pada kita untuk mengadakan perbaikan (revisi).

Jika dilihat dari hasil pada siklus I yang dicapai ketuntasan individu hanya 18 orang yang tuntas dan ketuntasan klasikalnya $54.16 \%$, ini perlu ditingkatkan lagi hasil ketuntasan belajar siswa agar tujuan pembelajaran tercapai dan memenuhi ketuntasan individu dan klasikal. Hasil belajar ini dapat dijadikan dasar untuk memperbaiki dan meningkatkan proses pembelajaran berikutnya, seperti yang diungkapakn Slameto (2010) bahwa evaluasi dapat member motivasi bagi guru dan siswa, mereka akan lebih giat belajar dan meningkatkan proses berpikir

Pelaksanaan Siklus II pada pertemuan 3 adalah guru harus banyak pengarahan kepada siswa saat penyampai materi agar siswa lebih siap memperhatikan penjelasan guru dan memberikan teguran kepada siswa yang tidak mau bekerjasama dengan teman kelompoknya. Pada siklus II, pembelajaran model inkuiri terbimbing kembali dilaksanakan. Dimana kekurangan-kekurangan pada siklus I sudah dapat diperbaiki sedikit demi sedikit, siswa juga lebih siap melaksanakan pembelajaran model inkuiri terbimbing serta lebih berfokus terhadap penjelasan guru dan mau mengajukan pertanyaan jika terdapat kesulitan dalam menyelesaikan soal-soal LKPD yang diberikan.

Berdasarkan hasil evaluasi pada siklus II pertemuan 3 siswa memperoleh nilai $\geq 75$ sebanyak Sembilan belas orang atau sebanyak $79.16 \%$ ini berarti mengalami peningkatan dibandingkan hasil evaluasi pada siklus I, meliha hasil tes tindakan siklus II pertemuan 3 ini belum mencapai indikator keberhasilan yang telah ditetapkan penelitian maka dilanjutkan kembali pada pertemuan 4. Hal-hal yang harus diperbaiki pada siklus II pertemuan 4 adalah guru harus membimbing siswa dalam mengerjakan soal-soal yang diberikan. Setelah siklus II pertemuan 4, nilai siswa menunjukan lagi peningkatan menjadi 92\% siswa telah mencapai $\geq$ $85 \%$ atau indikator keberhasilan telah mencapai ketuntasan peningkatan hasil belajar siswa pada siklus II pertemuan 4 disebabkan pembelajaran model inkuiri terbimbing sudah dipahami oleh siswa sehingga siswa lebih siap dan termotivasi untuk belajar.

Sejalan dengan ini telah mencapai indikator yang telah ditetapkan. Sedangkan hasil observasi terhadap pelaksanaan pembelajaran bisa dikatakan baik, yakni komponen dalam scenario telah dilaksanakan dengan baik sesuai dengan yang di inginkan. 


\section{Aktivitas Siswa}

Aktivitas siswa dalam pembelajaran model inkuiri terbimbing pada konsep aljabar dilihat dari terlaksananya atau tidaknya pembelajaran dengan 5 indikator yang diamati. Berdasarkan pengamatan yang dilakukan terlihat bahwa dari siklus I ke siklus II, aktivitas siswa mengalami peningkatan. Ini menunjukkan siswa menjadi lebih efektif. Menurut Sudjana.N (2009) menekankan bahwa keefektifan berkenaan dengan jalan, upaya, teknik,strategi yang digunakan dalam mencapai tujuan secara tepat dan cepat. Dengan adanya peningkatan aktivitas siswa dapat disimpulkan bahwa pembelajarn sudah berpusat pada siswa.

Pembelajaran matematika yang menggunakan pembelajaran model inkuiri terbimbing selama pembelajaran berlangsung siswa terlihat cukuf aktif, selain mendengar penjelasan guru dan siswa lain. Jadi pembelajaran matematika yang menggunakan model pembelajaran inkuiri terbimbing dapat memberikan kesempatan kepada siswa untuk terlibat aktif dalam proses pembelajran untuk menemukan sendiri jawaban atas konsep-konsep yang mereka pelajari

Aktivitas siswa dalam pembelajaran dengan menggunakan model inkuiri terbimbing pada konsep aljabar ada menunujukkan peningkatan dari siklus I ke siklus II. Aktivitas siswa yang mengalami peningkatan dari siklus I ke siklus II pada kategori menyimak penjelasan guru, merumuskan masalah dan mencari jawaban sementara, melakukan pengamatan atau penyelidikan, diskusi kelompok, dan mempresentasikan sudah baik

Kecenderungan meningkat ini dikarenakan dalam proses pembelajaran diperlukan adanya bimbingan dalam belajar. Siswa memerlukan bantuan berupa petunjuk umum untuk belajar secara efektif dan efesien. Menurut Slameto (2011), kebutuhan siswa secara intern untuk mengetahui dan mengerti sesuatu yakni kebutuhan akan rasa ingin tahu, mendapatkan pengetahuan, informasi dan untuk mengerti sesuatu membuat siswa terlibat secara aktif dalam belajar.

Berdasarkan peningkatan aktivitas siswa yang telah dijelaskan di atas dapat disimpulkan bahwa pembelajaran sudah terpusat pada siswa. Sejalan dengan pendapat Trianto (2009), Pembelajaran yang sudah terpusat pada siswa dapat dikatakan bahwa pembelajaran tersebut sudah efektif karena penyampaian materi pada guru terjadi interaksi yang baik oleh guru dan siswa serta persyaratan untuk keaktifan pengajaran yaitu persentase waktu bagi siswa yang tinggi dicurahkan terhadap KBM dan rata-rata perilaku melaksanakan tugas yang tinggi diantara siswa.

Pada siklus I pertemuan 1 masih banyak temuan kekurangan terutama dalam pengelolaan kelas, dari 10 kategori yang ditentukan hanya 3 saja tidak dilakukan oleh siswa selama proses pembelajaran berlangsung. Hal ini terjadi karena siswa belum sepenuhnya berfokus terhadap pembelajaran dengan menggunakan model inkuiri terbimbing.

Pada siklus I pertemuan 2 hasil observasi menunjukkan berkurangnya persentase aktivitas yang seharusnya tidak dilakukan oleh siswa. Hal ini dikarenakan mulai adanya minat dan perhatian siswa. Namun masih banyak siswa yang mengerjakan tugas lain dan melamun. Hal ini menunjukkan tidak sepenuhnya siswa berfokus terhadap pembelajaran menggunakan model inkuri terbimbing. 
Aktivitas ketidakterlibatan siswa dalam pembelajaran pada siklus II menurun dibandingkan pada siklus I. pada siklus I rata-rata aktivitas yang seharus tidak dilakukan oleh siswa sebesar 23\% dan menurun pada siklus II menjadi $21 \%$, , hal ini menunjukkan sudah membaiknya minat dan perhatian siswa terhadap proses pembelajaran menggunakan model inkuri terbimbing dengan mengurangi aktivitas yang seharusnya tidak dilakukan oleh siswa juga didukung oleh usaha guru yang terus menerus memberikan motivasi dan membimbing terhadap siswa dalam pelaksanaan pembelajaran model inkuiri terbimbing.

Peran guru sebagai seorang pembimbing untuk mengembangkan sikap dan tingkah laku serta nilai-nilai sosial siswa telah berjalan. Peran guru adalah sebagai komunikator, sahabat yang dapat memberikan nasihat-nasihat, motivator sebagai pemberi inspirasi dan dorongan, pembimbing dalam pengembangan sikap dan tingkah laku serta nilai-nilai orang yang menguasai bahan yang diajarkan. Menurut Djamarah dan Zain (2006) guru mengatur strategi pengajarannya yang sesuai dengan gaya-gaya belajar anak didik.

Hambatan yang ditemukan guru dalam proses belajar mengajar yaitu mengalami kesulitan dalam melakukan pengamatan karena pembelajaran ini masih sangat baru dilakukan dan siswa masih bingung dengan model pembelajaran inkuiri terbimbing. Proses pembelajaran pada siswa juga harus didukung dengan peningkatan pengelolan pembelajaran oleh guru.

\section{Respon Siswa}

Respon siswa terhadap model pembelajaran yang diterapkan oleh guru terhadap konsep aljabar dapat diterima dengan respon yang baik dalam proses belajar mengajar. Menurut Sudjana.N (2009) dapat diketahui bagaimana sikap dan perilaku siswa, kegiatan yang dilakukannya, tingkat partisipasi dalam suasan kegiatan, proses kegiatan yang dilakukannya, bahkan hasil yang diperoleh dari kegiatannya.

Berdasarkan data yang diperoleh menunjukan respon siswa setelah proses pembelajan siswa dengan menggunakan model inkuri terbimbing adalah positif. Hal ini menandakan behwa penggunaan model inkuiri terbimbing telah diterima siswa. Siswa merasa senang selama mengikuti pembelajaran dengan mengunakan model inkuiri terbimbing. Siswa memperoleh banyak manfaat setelah mengikuti pembelajaran dengan model inkuiri terbimbing diantaranya dapat melatih kerjasama dalam kelompok, aktif dalam kegiatan pembelajaran dan mudah memahami pelajaran. Selama proses belajar dengan model inkuiri terbimbing, rata-rata siswa merasa senang untuk termotivasi belajar, dan menyarankan agar lebih ditingkatkan untuk menggunakan model inkuri terbimbing.

Hal ini sesuai dengan pernyataan Slameto (2010) mengembangkan minat terhadap sesuatu pada dasarnya adalah membantu siswa melihat bagaimana hubungan antara materi yang diharapkan untuk dipelajarinya dengan dirinya sendiri sebagai individu. Proses ini menunjukkan pada siswa bagaimana pengetahuan atau kecakapan tertentu mempengaruhi dirinya, melayani tujuantujuannya, memuaskan kebutuhan-kebutuhannya. Bila siswa menyadari bahwa 
belajar merupakan suatu alat untuk mencapai beberapa tujuan yang dianggapnya penting, dan bila siswa melihat bahwa hasil dari pengalaman belajarnya akan membawa kemajuan pada dirinya, kemungkinan besar ia akan berminat dan bermotivasi untuk mempelajarinya.

\section{A. KESIMPULAN}

\section{KESIMPULAN DAN SARAN}

Berdasarkan hasil penelitian dan pembahasan tentang meningkatkan pemahaman konsep aljabar siswa SMPN 1 Kusan Hilir dengan menggunakan model pembelajaran inkuiri terbimbing, dapat disimpulkan sebagai berikut:

a. Pemahaman siswa kelas VII E SMPN 1 Kusan Hilir pada konsep aljabar menggunakan model pembelajaran inkuiri terbimbing mengalami peningkatan pada siklus I ketuntasan klasikal postes pada pertemuan 1 yaitu 29,16\% dan $54,16 \%$ pada postes pertemuan 2 . dan siklus II ketuntasan klsikal postes pertemuan 3 yaitu $79,16 \%$ dan menjadi $92 \%$ pada pertemuan 4 .

b. Keterampilan proses matamatika siswa kelas VII E SMPN 1 Kusan Hilir dalam pembelajaran konsep aljabar menggunakan model inkuiri terbimbing terjadi peningkatan pada setiap siklusnya. Hal ini ditunjukan dengan nilai ratarata 79,5 pada siklus 1 , dan 87,44 pada siklus 2 .

c. Aktivitas siswa Kelas VII E SMPN 1 Kusan Hilir dalam proses belajar mengajar pada konsep aljabar menggunakan model inkuiri terbimbing terjadi perubahan yang baik. Hal ini ditujukkan dengan aktivitas siswa yang semakin meningkat dari siklus I ke siklus II

d. Respon siswa kelas VII E SMPN 1 Kusan Hilir dengan menggunakan model pembelajara inkuiri terbimbing pada konsep aljabar memberikan respon yang Baik .

\section{B. Saran-Saran}

Diharapkan kepada guru bidang studi matematika untuk dapat menjadikan model pembelajaran inkuiri terbimbing ini sebagai alternative pembelajaran, terlebih pada konsep aljabar sehingga dapat meningkatkan pemahaman dan keterampilan proses matematika siswa pada pembelajaran.

\section{DAFTAR PUSTAKA}

Ahmadi, Khoiru. 2011. Strategi Pembelajaran Berorientasi KTSP. Jakarta: Prestasi Pustakaraya.

Arikunto, Cepi Sapruddin Abdul Jabar. 2004. Evaluasi Program Pendidikan.Jakarta: Bumi Aksara

Arikunto, Suharsimi. 2010. Prosedur Penelitian Suatu Pendekatan Praktek.Jakarta: Rineka Cipta

Arifin Zainal, 2012. Evaluasi Pembelajaran. Bandung: Remaja Rosdakarya. 
Aqib, Zainal, dkk, 2008, Penelitian Tindakan Kelas Untuk Guru SMP, SMA, SMK. Bandung: Yrama Widya

Dzamarah, 2008. Psikologi Belajar. Jakarta: Rineka Cipta.

Dalyono, 2010. Psikologi Pendidikan.Jakarta: Rineka Cipta

Fathurrohman, Pupuh dan Sutikno, Sobry. 2007. Strategi Belajar Mengajar. Bandung: Refika Aditama.

Kunandar, 2009. Penelitian Tindakan Kelas. Jakarta: Rajagrafindo Persada

Mary Jane, 2008, Aljabar For Dummies, Departemen Pendidikan Nasional : Pakar Raya

Nuharini, Dewi, 2008 Matematika Konsep dan Aplikasinya. Jakarta: Pusat Perbukuan

Negoro,ST,2000.Enseklopedia Matematika.Jakarta:Ghalia Indonesia

Noehi, 2008. Evaluasi pengajaran. Jakarta: Universitas Terbuka

Popham, James. 2008. Teknik Mengajar Secara Sistematis. Jakarta: Rineka Cipta

Rusman, 2011. Model-model Pembelajaran. Jakarta: Rajagrafindo Persada.

Rusman, Deni Kurniawan, Cepi Riana, 2011. Pembelajaran Berbasis Teknologi Informasi dan komunikasi.Jakarta: Rajagrafindo Persada.

Roestiyah. 2008. Strategi Belajar Mengajar. Jakarta: Rineka Cipta

Sanjaya, W. 2011.Strategi Pembelajaran Berorientasi Standar Proses Pendidikan. Kencana Prenada Media Group: Jakarta.

Suharsimi, 2010. Prosedur Penelitian. Jakarta: Rineka Cipta.

Sumiati, Asra. 2007. Metode Pembelajaran. Bandung: Wacana Prima

Slameto. 2011. Belajar dan Faktor-Faktor yang Mempengaruhinya. Jakarta: Asdi Mahasatya.

Sudjiono, A. 2009. Pengantar Statistik Pendidikan. Jakarta: Rajawali pers.

Sukidin, dkk. 2007. Manajemen Penelitian Tindakan Kelas. Jakarta : Insan Cendekia.

Trianto, 2010. Mendesain Model Pembelajaran Inovatif-Progresif. Jakarta: Kencana Prenada Media Group.

Usman, Uzer, 2001. Menjadi Guru Profesional. Bandug: Remaja Rosdakarya.

Winataputra, 2007. Strategi Belajar Mengajar. Jakarta: Universitas Terbuka 